\title{
Kan Kültürï Şişesinden Doğrudan Yapılan Antibiyogram için Yöntemin Optimizasyonu
}

\author{
Aynur EREN TOPKAYA, Özge TOMBAK \\ Namık Kemal Üniversitesi, Tıp Fakültesi, Tıbbi Mikrobiyoloji Anabilim Dalı
}

Sayın Editör,

Kan dolaşımı enfeksiyonlarının tanısı klinik mikrobiyoloji laboratuvalarının acil işlerinden birisidir. Sepsisli olguların ancak \%35'inde kültürde pozitiflik olduğu bildirilmektedir. Buna rağmen kan kültürü halen kan ve dolaşım sistemi enfeksiyonlarının mikrobiyolojik tanısında altın standarttır. Kan kültürlerinden enfeksiyon etkeni mikroorganizmaların en kısa zamanda ve doğru olarak tespit edilip hastanın uygun antibiyotik ile erken tedavi edilmesi morbidite ve mortalite ile doğrudan ilişkilidir. Bu nedenle; bakteriyemi, ciddi sepsis ve sistemik enflamatuar cevap sendromunun tanısında kan kültürü ile elde edilen sonuçların hızlandırılması için doğrudan kültür şişesinden yapılan, etkeni tanımlama ve antimikrobiyal direnç mekanizmalarının saptanması ile ilgili farklı yöntemlerin denendiği çalışmalar yapılmıştır ${ }^{(1-3)}$. $\mathrm{Bu}$ çalışmalarda, moleküler yöntemler ile elde edilen tanımlama ve antibiyotik duyarlılık sonuçlarının, subkültürlerden konvansiyonel yöntemlerle yapılanlarla yüksek oranda uyumlu olduğu belirtilmiştir. Kan kültür şişesinden doğrudan yapılan antibiyogramların da benzer şekilde subkültürden yapılanlarla karşılaştırıldığında yüksek uyumluluk gösterdiği, ancak inoküle edilen bakteri sayısı ve sonuçların yorumlanması açısından bu yöntemin optimizasyonuna gereksinim olduğu belirtilmiştir $^{(4,5)}$.

Bu çalışmada, kan kültüründe üreyen 23 gram pozitif ve 17 gram negatif etken bakteri için kültür şişelerinden seri dilüsyonlar hazırlanarak kantitatif ekimler yapılmış ve 105 koloni oluşturan bakteri/mL bakteri sayısının 1/100 dilüsyon ile sağlandığı saptanmıştır. Bu şekilde yapılan disk difüzyon test sonuçları ile subkültürden CLSI önerilerine göre yapılan antibiyotik duyarlılık test sonuçları CLSI standartlarına göre yorumlanarak karşılaştırılmiştir.

Çalışmamızın sonuçlarına göre; Gram negatif bakteriler için doğrudan duyarlılık testi ile subkültürden yapılan duyarlılık testi arasında saptanan uyum oranı $13 / 17$ 'dir. Toplam hata oranı 4/17 olup bunların birinde sefepim için çok büyük hata; birinde siprofloksasin için büyük hata; ve ikisinde de amikasin için minör hata saptanmıştır. Toplam 23 gram pozitif bakterinin 20'si Staphylococcus spp. ve 3'ü Enterococcus spp. idi. Gram pozitifler için; çok büyük hata 2/ 23 oranda trimetoprim/sülfametaksazol ve levofloksasin için, büyük hata $1 / 23$ oranda vankomisin için saptanmış olup duyarlılık sonuçları arasında 20/23 uyum olduğu tespit edilmiştir.

Sonuç olarak, pozitif kan kültüründen izole edilen organizmaların antibiyotik duyarlılıklar1nın subkültürlerden konvansiyonel yöntemler kullanılarak saptanması yaklaşık 48 saati bulmakta ve bu gecikme, ciddi enfeksiyonu olan hastalarda kritik sonuçlara yol açmaktadır.

\footnotetext{
Alındığı tarih: 25.06 .2016

Kabul tarihi: 30.06 .2016

Yazışma adresi: Aynur Eren Topkaya, Namık Kemal Üniversitesi Tıp Fakültesi, Tıbbi Mikrobiyoloji Anabilim Dalı, Tekirdağ e-posta: aetopkaya@nku.edu.tr
} 
Pozitiflik saptanan kan kültürü şişesinden alınan örneğin 1/100 dilüsyonu ile doğrudan duyarlılık testi yapılması bu süreyi yarıya indirerek önemli bir avantaj sağlamış olacaktır. Bu konuda, kan dolaşımı enfeksiyonu etkeni olan bakteri türleri için ayrı ayrı ve daha çok sayıda kökeni içeren çalışmalarn yapılmasına gereksinim vardır, ancak bu çalışmanın bulguları umut vericidir. Yeni yapılacak olan çalışmalarda, bir yandan subkültür ile antibiyotik duyarlılık testleri tekrarlanırken, bir yandan da direkt ekim ile yapılan antibiyotik duyarlılık testleri sonucu 'ön tanı' olarak rapor edilebilir ve 'kesin sonuç bir gecelik inkübasyon sonrasında çıkacaktır' ibaresi eklenebilir.

\section{KAYNAKLAR}

1. Fujita S, Yosizaki K, Ogushi T, Uechi K, Takemori Y, Senda Y. Rapid identification of gram-negative bacteria with and without CTX-M extended-spectrum $\beta$-lactamase from positive blood culture bottles by PCR followed by microchip gel electrophoresis, J Clin Microbiol 2011; 49:1483-8. http://dx.doi.org/10.1128/JCM.01976-10

2. Cleven BE, Palka-Santini M, Gielen J, Meembor S, Krönke M, Krut O. Identification and characterization of bacterial pathogens causing bloodstream infections by DNA microarray, J Clin Microbiol 2006; 44:238997. http://dx.doi.org/10.1128/JCM.02291-05

3. Naas T, Cuzon G, Truong H, Bernabeu S, Nordmann P. Evaluation of a DNA microarray, the check-points ESBL/KPC array, for rapid detection of TEM, SHV, and CTX-M extended-spectrum beta-lactamases and KPC carbapenemases, Antimicrob Agents Chemother 2010; 54:3086-92. http://dx.doi.org/10.1128/AAC.01298-09

4. Coyle MB, McGonagle LA, Plorde JJ, Clausen CR, Schoenknecht FD. Rapid antimicrobial susceptibility testing of isolates from blood cultures by direct inoculation and early reading of disk diffusion tests, $J$ Clin Microbiol 1984; 20:473-7.

5. Chapin KC, Musgnug MC. Direct susceptibility testing of positive blood cultures by using Sensititre broth microdilution plates, J Clin Microbiol 2003; 41:4751-4.

http://dx.doi.org/10.1128/JCM.41.10.4751-4754.2003 